\title{
A Comparison of the South African and United States Models of Natural Areas Management
}

\author{
Daniel S. Licht, ${ }^{1}$ Brian C. Kenner, ${ }^{2}$ and Daniel E. Roddy ${ }^{3}$ \\ ${ }^{1}$ National Park Service, 231 East Saint Joseph Street, Rapid City, SD 57701, USA \\ ${ }^{2}$ Badlands National Park, Interior, SD 57750, USA \\ ${ }^{3}$ Wind Cave National Park, Hot Springs, SD 57747, USA \\ Correspondence should be addressed to Daniel S. Licht; dan_licht@nps.gov
}

Received 31 October 2013; Accepted 15 December 2013; Published 28 January 2014

Academic Editors: P. K. S. Shin and P. M. Vergara

Copyright (C) 2014 Daniel S. Licht et al. This is an open access article distributed under the Creative Commons Attribution License, which permits unrestricted use, distribution, and reproduction in any medium, provided the original work is properly cited.

\begin{abstract}
In May-June of 2013 we visited several South African parks and reserves to learn about wildlife and natural areas management in that country. We focused our visit on parks and reserves that are of moderate size (5,000-100,00 ha), comprised of grassland/savanna habitats, located within agrarian landscapes, and enclosed with boundary fences, characteristics similar to several parks and reserves in the Northern Great Plains region of the United States. In this paper we compare the South African model of natural areas management to the United States model. We observed that South African parks and reserves with the aforementioned characteristics are more likely to (1) reintroduce and conserve small, nonviable wildlife populations, (2) reintroduce and conserve top-level predators, (3) have more intensive management of wildlife, (4) manage in partnership across multiple landowners, (5) engage local communities, (6) be self-funding, and (7) restrict visitor movement. The South African model is arguably more effective in conserving biodiversity as measured by conservation of apex predators and natural processes. The differences between the countries appear to be driven in large part by socioeconomic factors. Knowledge of natural areas management in other countries may lead to more innovative and creative models that could benefit biodiversity conservation.
\end{abstract}

\section{Introduction}

The United States is often perceived and portrayed as a leader in natural areas management [1], a perception that has some merit considering that the country established Yellowstone National Park in 1872, arguably the world's first national park. Over time a convention and mode of natural areas management evolved in the USA [2]. At the same time other countries were establishing parks and reserves and developing their own management models [1]. South Africa is one such country that is now widely recognized for its innovative and progressive park and reserve management.

With that in mind, the authors went to South Africa, met with colleagues there, and reviewed wildlife and natural areas management in that country. Many of the parks and reserves in South Africa are similar to natural areas in the Northern Great Plains region of the United States in that they are moderate in size (5,000-100,00 ha), they conserve grassland and savanna ecosystems, and they are fenced and/or surrounded by agrarian landscapes. In this paper we qualitatively identify and discuss the most notable differences we observed between the two countries in terms of natural areas management and biodiversity conservation. We did not use a quantitative approach for comparing the effectiveness of biodiversity conservation in the two countries as there are confounding factors such as differing baseline levels of species richness [3] that make such an approach problematic. Our goal is to expose the reader to varying forms of natural areas management in hope that it may lead to better conservation of biodiversity.

\section{The South African Model versus the United States Model}

It is somewhat misleading to say that a country has a "model" for natural areas management and to starkly compare that model against another country's model, as most countries 
have a myriad of approaches toward natural areas management and conservation. For example, in South Africa the parks and reserves range from the vast and open Kalahari Gemsbok National Park to small and closed parks near urban areas; management practices and policies vary greatly between these sites. Likewise, within the United States national park management practices vary greatly between Yellowstone National Park and smaller parks near population centers. Yet when comparing "apples to apples," specifically moderate-size grassland/savanna parks located within agrarian landscapes and surrounded by boundary fences, there are significant and noteworthy differences between the two countries. We summarize these differences in Table 1 . In the following sections we elaborate on these differences.

2.1. Wildlife Management. Perhaps the most striking difference between the two countries from a biodiversity perspective is that South African parks and reserves actively reintroduce, conserve, and manage very small populations of wildlife, including apex predators. This is generally done for purposes of (1) restoring an ecological process, and, (2) generating wildlife-related tourism revenue. Notable species that are commonly reintroduced into small parks and reserves in South Africa include the African lion (Panthera leo), African elephant (Loxodonta africana), black rhinoceros (Diceros bicornis), white rhinoceros (Ceratotherium simum), African buffalo (Syncerus caffer), wildebeest (Connochaetes sp.), and African wild dog (Lycaon pictus). Of those, only the black rhinoceros and African wild dog are generally considered as critically endangered in the wild.

Funston [4] compiled a list of private and public protected areas in southern Africa that reintroduced lions since 1992; ten sites were 10,000 ha or less and three were 2,500 ha or less. The smallest site was the privately owned 1,500 ha Madjuma Game Reserve. In several cases the reserves are so small that they could conserve only a single pride of lions comprised of only a few individuals. Many similar size reserves also conserve small populations of elephants, rhinoceroses, and other large-bodied mammals. Even wideranging species, such as the African wild dog, have been reintroduced into sites as small as 8,500 ha [5]. Lindsey et al. [5] established minimum reserve sizes for reintroduction of wild dogs (6,500-14,700 ha) based on the criteria of being able to support a single family unit.

The reintroduction of small populations of large-bodied wildlife into small fenced reserves in South Africa is done more for restoring ecological processes or promoting ecotourism than it is for the global conservation of the species (Figure 2). Funston [4] noted that most South African sites with lions are managed to meet the goals for the site (primarily ecotourism); however, he also noted that such sites have the potential for meaningful conservation of the species if metapopulation guidelines are followed. A metapopulation approach, relying on a network of large and medium size reserves, has been proposed for wild dogs and may be critical for survival of the species in South Africa [6].

The reintroduction and conservation of micropopulations of wildlife in small reserves are commonplace in
South Africa; however, there are challenges and necessities associated with such a model. Kettles and Slotow [7] list the issues as overpopulation, inbreeding depression, decline of prey and other predator species, conflict with neighboring communities, and, in some cases, spreading disease. For example, a micropopulation of lions caused the decline of some prey species at the small and fenced Madjuma Game Reserve, whereas other prey species increased in abundance following the lion reintroduction; these unanticipated events resulted in reserve managers removing the lion population [8]. Similar undesirable effects have been noted for reintroductions of African wild dogs to small closed reserves [5].

Mitigating these problems requires active intervention in what Funston [4] called "micromanagement." Kettles and Slotow [7] list the possible interventions as "relocation, contraception, hunting, and artificial takeovers." Such micromanagement is often costly and contentious, but usually technologically feasible. In discussing lion management Kettles and Slotow [7] noted that "none of the intervention methods resulted in long-term behavioural or social consequences. Constraints on lion management were more from societal values than biological or technological influences. If applied in the correct manner, at the correct time, all of these interventions, or a combination of them, can assist in achieving management objectives."

One factor that may facilitate the South African micromanagement or hands-on approach is that in South Africa wildlife is not "owned" by the state. Therefore, wildlife can readily be bought, sold, transferred, and managed. In contrast, wildlife in the United States is "owned," or held in trust, by the states or, when specifically identified by Congress, by the federal government. In general, private ownership of wildlife is uncommon and illegal in many cases.

Furthermore, in contrast to the South African model, the reintroduction of micropopulations to small parks and reserves, as well as the associated interventionist management, is discouraged in U.S. parks and reserves. In the case of national parks this reluctance is reaffirmed by National Park Service policies that call for reintroductions only when the population can be "self-perpetuating" [9]. We know of only a few examples that challenge this requirement. One example is Wind Cave National Park which recently reintroduced the black-footed ferret (Mustela nigripes) even though the 2,500 acres of black-tailed prairie dogs (Cynomys ludovicianus) within the park may only support about 30 ferrets and be inadequate for long-term viability. This reluctance and discouragement to conserve small and non-viable populations is why none of the parks and reserves in the Northern Great Plains region of the United States support the full native faunal community whereas many comparable size parks and reserves in South Africa do conserve the full wildlife community.

Perhaps the most striking difference between the two countries and their management models is expressed in terms of apex predators (Figure 1). The United States has no precedence or model for reintroducing and conserving small populations of apex predators in closed protected areas. Wolves (Canis lupus) have been restored in the Western United States, but only to the vast wildernesses of 
TABle 1: Notable differences between natural areas management in South Africa and the United States.

\begin{tabular}{|c|c|c|}
\hline Issue & South Africa & United States \\
\hline $\begin{array}{l}\text { Park/reserve } \\
\text { purpose }\end{array}$ & $\begin{array}{l}\text { Conservation of wildlife, especially charismatic } \\
\text { megafauna, for ecotourism. Many private reserves } \\
\text { were established for commercial purposes. }\end{array}$ & $\begin{array}{l}\text { Conservation of scenery and landscapes, evolved to } \\
\text { include the conservation of wildlife and ecosystems } \\
\text { for public benefits. }\end{array}$ \\
\hline $\begin{array}{l}\text { Conservation of } \\
\text { small populations }\end{array}$ & $\begin{array}{l}\text { More likely to reintroduce and conserve small } \\
\text { nonviable populations. }\end{array}$ & $\begin{array}{l}\text { Policies and traditions often discourage } \\
\text { reintroduction of small nonviable populations. }\end{array}$ \\
\hline Apex Predators & $\begin{array}{l}\text { Apex predators are reintroduced into reserves as small } \\
\text { as } 5,000 \text { ha. }\end{array}$ & $\begin{array}{l}\text { Apex predators are only reintroduced to large } \\
\text { landscapes. }\end{array}$ \\
\hline $\begin{array}{l}\text { Management } \\
\text { Intervention }\end{array}$ & $\begin{array}{l}\text { Very hands-on management, necessitated in part by } \\
\text { the small populations and presence of apex predators. }\end{array}$ & $\begin{array}{l}\text { A more hands-off approach, sometimes directed by } \\
\text { agency policies. }\end{array}$ \\
\hline $\begin{array}{l}\text { Active } \\
\text { metapopulation } \\
\text { approach }\end{array}$ & $\begin{array}{l}\text { Routine transfer of animals between sites for } \\
\text { demographic and genetic augmentation, revenue } \\
\text { generation, and other reasons. }\end{array}$ & $\begin{array}{l}\text { Less frequent transfer of animals between sites, } \\
\text { especially into existing populations. Generally done } \\
\text { only when species is threatened with extirpation. }\end{array}$ \\
\hline Boundary fences & $\begin{array}{l}\text { Routinely used for natural areas and required by law } \\
\text { for some species. }\end{array}$ & Generally discouraged. Used primarily for bison. \\
\hline Water management & $\begin{array}{l}\text { Trend toward removal of anthropogenic water for } \\
\text { purposes of restoring ecosystem integrity and } \\
\text { heterogeneity; however, many units retain } \\
\text { anthropogenic water for wildlife viewing. }\end{array}$ & $\begin{array}{l}\text { Water management generally avoided unless critical } \\
\text { for species restoration, sometimes done for purposes } \\
\text { of uniform range utilization and increased carrying } \\
\text { capacity. }\end{array}$ \\
\hline $\begin{array}{l}\text { Partnerships across } \\
\text { land ownerships }\end{array}$ & $\begin{array}{l}\text { Commonly used to create and expand natural areas. } \\
\text { Typically enforced with a legal document. } \\
\text { Management often conferred to a single entity. }\end{array}$ & $\begin{array}{l}\text { Less frequently used, rarely with a legal document, } \\
\text { and partners maintain their own management. }\end{array}$ \\
\hline $\begin{array}{l}\text { Park/reserve } \\
\text { expansion }\end{array}$ & $\begin{array}{l}\text { Protected area boundaries regularly expand due in } \\
\text { large part to new partnerships. }\end{array}$ & Boundary changes and expansion much less frequent. \\
\hline $\begin{array}{l}\text { Community } \\
\text { involvement and } \\
\text { benefits }\end{array}$ & $\begin{array}{l}\text { Natural areas are often established for community } \\
\text { benefits or have evolved to emphasize those benefits, } \\
\text { including resource utilization by local communities. } \\
\text { Parks/reserves actively involve local communities via } \\
\text { regular and routine meetings. }\end{array}$ & $\begin{array}{l}\text { Community involvement and benefits are more } \\
\text { passive. Generally, public engagement is limited to } \\
\text { more formal meetings intended to get public input on } \\
\text { specific, proposed management actions or plans. }\end{array}$ \\
\hline Ecotourism & $\begin{array}{l}\text { Ecotourism and hunting are used to justify, create, and } \\
\text { operate many reserves. }\end{array}$ & $\begin{array}{l}\text { Ecotourism often viewed as passive benefit of natural } \\
\text { areas, but is not typically a primary objective. }\end{array}$ \\
\hline Park funding & $\begin{array}{l}\text { National parks get about } 20 \% \text { of operating funds from } \\
\text { appropriations, rest from gate receipts, wildlife sales, } \\
\text { and other sources. Private reserves funded from } \\
\text { ecotourism, wildlife sales, and hunting. }\end{array}$ & $\begin{array}{l}\text { Almost all park funding comes from government } \\
\text { appropriations. In the case of reserves managed by } \\
\text { nonprofit organizations, from donations. }\end{array}$ \\
\hline Visitor experiences & $\begin{array}{l}\text { Visitation is highly restricted. Visitors, only able to } \\
\text { enter/leave within daylight hours and must stay in } \\
\text { vehicles in reserves with dangerous animals unless on } \\
\text { ranger-led activities. }\end{array}$ & $\begin{array}{l}\text { Visitors generally allowed to freely travel on foot, via } \\
\text { vehicle or horseback. }\end{array}$ \\
\hline $\begin{array}{l}\text { Outreach and } \\
\text { interpretation }\end{array}$ & $\begin{array}{l}\text { Small visitor centers with rudimentary interpretive } \\
\text { displays and information. }\end{array}$ & $\begin{array}{l}\text { Larger and more state-of-the-art visitor centers } \\
\text { utilizing modern technology. }\end{array}$ \\
\hline
\end{tabular}

the Yellowstone Ecosystem and the Southwest United States. Nowhere have wolves been reintroduced to parks or reserves similar to what has occurred with lions and wild dogs in South Africa, although the idea has recently been broached in the scientific literature [10]. The reluctance to consider such a model in the USA has many reasons, including the hands-off non-interventionist approach endorsed by agency policies. The current situation at Isle Royale National Park in Lake Superior is noteworthy. In the 1940s wolves got established on the 53,500 ha island park by crossing an ice-bridge from the mainland. The population grew to a long-term average of about 25 animals, but has been in decline for the past several years. The conservation and scientific community is currently debating whether wolves should be translocated to the island for genetic and/or demographic augmentation of the existing population [11]. Based on our observations there would be little if any hesitation to augment or reintroduce wolves to Isle Royale under the South African model.

A prerequisite for reintroducing lions, elephants, and other large mammals into reserves in South Africa is the establishment of a fence. Electrified boundary fences are required by law for lions, wild dog, and elephants [12]. Fences greatly reduce conflicts with surrounding neighbors and protect people and property from the species; however, they also have the benefit of allowing for the conservation of the species [13]. Were it not for fences the animals would inevitably wander out of the small parks and reserves and probably be killed. Eventually that could lead to extirpation 


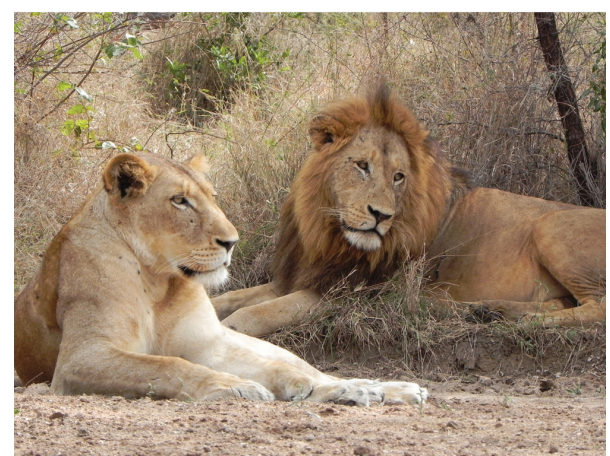

FIGURE 1: South African reserves as small as 5,000 ha restore lions for purposes of ecosystem stewardship and ecotourism. The restoration of small populations and in some cases single family units requires intensive management. The restoration of apex predators to small and medium size reserves is not done in the United States.

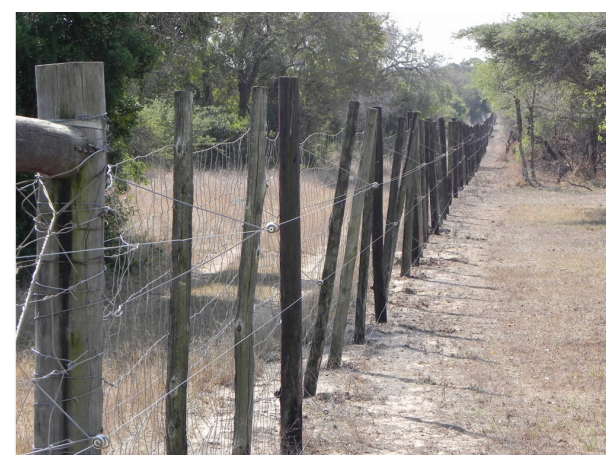

Figure 2: A perimeter fence around a South African reserve. In agrarian landscapes fences protect people and property and conserve wildlife populations. Wildlife within fenced African reserves is considered free ranging.

of the park population. Packer et al. [14] suggested that many unfenced African lion populations may decline to near extinction in the next $20-40$ years. They also noted that lion populations within fenced reserves are nearer their carrying capacities and are less expensive to manage. Fences are generally viewed negatively by the conservation community in the United States as they result in ecological problems, high costs, and aesthetic impairment. However, fences are used in the Great Plains to keep bison (Bison bison) from roaming out of parks and reserves. Boundary fencing has been a critical tool in the conservation of the species.

The differing philosophies and approaches towards wildlife management are epitomized by the use of two terms. In the United States the term "free ranging" is generally only applied to an animal outside of a fenced park or reserve; however, in South Africa the same term is often applied to an animal within a fenced reserve, provided the reserve has the minimum land size needed for the animal to meet its life needs. Or in the words of one South African ecologist, a free-ranging animal is one "that is not fed by people" (pers. comm. Sam Ferreira, Kruger National Park). In the United States the word metapopulation typically refers to a wildlife species whose global or regional population is comprised of several subpopulations that naturally interchange animals through dispersal. In contrast, the term metapopulation in South Africa generally refers to a population that is managed via anthropogenic translocation of animals between sites.

2.2. Partnerships. Conserving biodiversity often requires landscape approaches. In South Africa there are numerous examples of multiple landowners managing sites in partnership. In some cases the partners are a mix of public and private entities, in other cases the partnership may be comprised only of private landowners (these are sometimes referred to as conservancies). Government-sponsored partnerships also occur across national boundaries including between South Africa and neighboring Botswana, Namibia, Mozambique, and Zimbabwe. By establishing partnerships and removing fences between properties the landowners realize economies of scale and increase the site's potential for conserving biodiversity [15].

Welgevonden Game Reserve in north-central South Africa is one of many examples of a private partnership reserve. The 37,500 ha reserve is comprised of approximately 30 landowners who voluntarily became members of the reserve. Some landowners operate resorts and provide tourist activities such as safaris, whereas others maintain their properties for personal pleasure. However, in exchange for access to the entire reserve, all manage their land, operate their facilities, and make use of the reserve under a binding charter. The entire reserve, which hosts the Big 5 (African lion, African elephant, leopard, rhinoceros, and African buffalo) and other wildlife, is overseen by an elected board of governors. Another example of a multientity partnership is the 55,000 ha Madikwe Game Reserve in the North West Province. The site is run as a three-way partnership between the provincial government, local communities, and the private sector [16]. The success of Madikwe has led to the proposal of even more ambitious partnerships that would benefit local economies as well as biodiversity [17].

In contrast, the wealth of the United States has enabled the establishment of a wide range of government-run parks and reserves, perhaps to the exclusion of creative publicprivate partnerships. We know of no arrangements in the Northern Great Plains region of the United States similar to those of Welgevonden or Madikwe. Although neighboring land management agencies sometimes have memorandums of understanding and other cooperative documents, the agreements do not have the legal foundation, authority, commitment, or management scope of the multilandowner partnerships commonplace in South Africa. One promising scenario in the United States that could approach what we observed in South Africa is a site in southwestern South Dakota where the potential exists for three adjacent bison herds, one public (Badlands National Park), one tribal (a proposed tribal national park), and one private to be managed as one large herd under a partnership relationship similar to what is practiced in many South African reserves. 
2.3. Community Emphasis. We were struck by the emphasis of South African natural areas to provide essential community benefits. From the highest policy statements down to park and reserve operations there is an explicit emphasis in South Africa on working with and for local communities. This emphasis ranges from employing local people to (in the case of private reserves) making donations for community projects and infrastructure. However, it should be noted that this community emphasis is a relatively new model within South Africa. Historically, parks and reserves in that country were established and managed primarily for the pleasure and benefit of the wealthy and privileged white minority. But with the end of apartheid a new natural areas model evolved that has strong socio-economic and community development objectives. Even the vast transboundary parks and reserves build on the theme as a goal of those efforts is to achieve peace and prosperity in the region [18]. Fortunately, this community-emphasis model has facilitated conservation of Africa's charismatic wildlife species and biodiversity conservation.

An example of the new model is the Madikwe Game Reserve. The 1997 management plan for the site states "the approach towards conservation that has been adopted at Madikwe puts the needs of people before that of wildlife and conservation" [16]. The 55,000 ha reserve was initiated in 1991 following a feasibility study that determined that a wildlife reserve, and a wildlife-based tourism business, would be economically more profitable and self-sustaining than the apartheid-era cattle ranching and farming. As a result of the socio-economic assessment, the livestock were removed, wildlife-proof perimeter fences were constructed, and what may be the world's largest wildlife translocation, known as Operation Phoenix, was undertaken. As of 2003 the reserve directly supported almost 450 jobs [19]. Although there have been challenges and criticisms in terms of what types of realized community benefits, infrastructure development, and wildlife management $[20,21]$, the site has had enormous community, socio-economic, and biodiversity benefits, especially when compared to the prior land use.

We are not suggesting that South African parks and reserves generate more income or create more jobs than United States parks. USA parks provide substantial socioeconomic benefits to local communities. For example, Badlands National Park supported 317 jobs in 2011 and brought $\$ 22$ million to the local economy [22]. Many other USA parks have gateway communities that receive similar benefits from the parks. Yet these benefits are rarely the primary purpose, or even a secondary purpose, of the park or preserve. The socio-economic benefits realized by local communities in the USA are typically, from the management perspective of the agencies, indirect and passive. In contrast, in South Africa many parks and reserves now list community benefits as being a primary explicit objective for the site. And such an approach can result in substantial biodiversity benefits.

2.4. Budgets and Park Operations. In South Africa there is a saying that "the wildlife must pay their way," and wildlife has done that to an amazing extent. The ABSA Group
Economic Research [15] estimated that there were about 5,000 private commercial wildlife ranches and other 4,000 mixed wildlife/livestock farms in South Africa, encompassing $13 \%$ of the land area of the country. Many wildlife operations have been started in the past few decades. The country's transition to full democracy in 1994 led to the deregulation of the agricultural sector and a reduction in subsidies, thereby making many marginal rangelands unprofitable for cattle, goat, and sheep operations. Many landowners converted to wildlife operations. Some operations emphasize private hunting and/or generate revenue from wildlife sales. Others cater to nonconsumptive ecotourism, with large predators being critical attractions for ecotourism [23]. Lindsey et al. [24] found that wild dog conservation can pay for itself based on contingency valuation model and that ecotourism should be part of a multifaceted approach to wild dog conservation. Madikwe Game Reserve, established on former rangeland, and many other sites are self-funding operations [16]. South Africa has demonstrated that economics, jobs, and biodiversity can, in some cases, be mutually beneficial.

However, an economics-based model for wildlife conservation does have shortcomings even in South Africa. For example, at Madikwe Game Reserve prey populations are managed at carrying capacity so tourists have a high likelihood of seeing lions and leopards, to the detriment of rare and less competitive habitat specialists such as roan (Hippotragus equinus), sable (Hippotragus niger), and tsessebe (Damaliscus lunatus). Nevertheless, the site still conserves more biodiversity than the prior domestic livestock-based model.

There has been no comparable increase in the number or land area of private wildlife operations in the United States. Farm subsidies and cropland retirement programs remain substantial and temporary cropland set-asides are often supported by the conservation community, helping reinforce agrarian land uses. It has been suggested that the short-term set-asides preclude more beneficial and long-lasting conservation opportunities similar to those practiced in South Africa [25], yet agricultural subsidies and temporary set-asides are likely to remain a driving force in land use in the Great Plains. The availability of large amounts of accessible public land in the United States also makes private for-profit ecotourism operations more challenging. One could also argue that North American wildlife is less charismatic and less able to generate ecotourism revenue than South African wildlife. Wildlife-based operations comprise a relatively small portion of land use in the region. One notable exception is the increase in bison ranches; however, unlike in Africa, the purpose of these ranches is not to provide ecotourism or hunting but for meat production as a better option than traditional cattle ranching. In practice these operations are more similar to livestock operations than they are to wildlife reserves [26]. In spite of the economic obstacles to establishing private reserves in the United States, attempts are being made. The American Prairie Foundation (APF) project in Montana is a noteworthy example and has similarities to the South African model. That project hopes to recreate a vast self-funding prairie reserve out of marginal rangeland. The project has had many successes and 
continues to grow, although funding continues to primarily come through donations. In contrast to many South African ventures, neither the state nor federal government is an active supporter and promoter of the APF project.

2.5. Visitor Experiences. One dramatic difference between South African parks and reserves and those in the USA is the amount of freedom that visitors have to experience the site. For example, in most South African sites visitors must enter via manned gates during daylight hours. And visitors are rarely allowed to exit their vehicles except at designated spots. The restrictive policy is primarily due to the presence of lions, elephants, rhinoceros, leopards (Panthera pardus), and other dangerous animals. While the restrictions are primarily for visitor safety they likely also reduce harassment and disturbance of wildlife. In private reserves vehicle drives usually require a guide; a requirement that provides employment for local people and further protects the wildlife. In the U.S. visitors have much more open access and freedom to move about the site, including traveling via foot without a guide. Such unrestricted travel and nature-viewing experiences are encouraged. In rare cases parks and reserves may close certain areas, often temporarily, to protect critical denning areas, nesting sites, or other critical habitats.

Visitors to parks and reserves in South Africa and in the United States may have different expectations and goals. In South Africa wildlife is typically the star attraction, whereas in the United States wildlife often competes with geologic formations, outdoor recreation, and other features. This difference is illustrated by the fact that in South Africa park and reserve visitors go on "game drives" whereas in the USA they go "sightseeing." Our use of these terms is of course a generalization, but we believe that it fairly and accurately portrays the differing visitor objectives and experiences in the two countries. Consider that wildlife viewing, although a very popular activity in USA National Parks, does not typically rank as the most important reason that people visit parks [27]. In many parks, including parks established to conserve natural resources, sightseeing and viewing scenery more frequently ranked as the top activity for visitors. In South Africa, wildlife viewing is the top reason people visit most parks and reserves, with the ultimate goal of seeing the Big 5.

Based on our observations, interpretive and education materials and programs at parks are more prominent, technological, and state-of-the-art in the United States than they are in South Africa. However, we were struck by the power of some of the rudimentary interpretive displays we saw in South Africa and neighboring Swaziland. We observed large wallboard displays that were hand-drawn and hand-written by local school children. In this day and age of ubiquitous video displays, software programs, and computer-designed posters the presence and power of a home-made interpretive display can be profound.

\section{Conclusion}

In this paper we summarize and describe notable observed differences in natural areas management between South
Africa and the United States, with an emphasis on fenced mid-size natural areas in agrarian and human-dominated landscapes. We have made general statements and conclusions based on our observations, discussions, and research. Our perspective is strongly influenced by our extensive experience with moderate-size national parks in the Great Plains; others may come to slightly different conclusions and areas of emphasis based on their experiences.

From our perspective there are dramatic differences in how the two countries perceive and manage mid-size natural areas. In South Africa the reserves are more socioeconomically driven, yet ironically, they are better at conserving biodiversity, at least in terms of conserving large-bodied mammals, apex predators, and natural processes. Reserves in the United States rely less on ecotourism for their existence and therefore have less incentive to conserve charismatic megafauna. However, the South African model also comes with many challenges and costs.

We do not intend to convey that one model is better than the other as each has pros and cons and may be best suited for the milieu in which they occur. Yet other countries' models could and should be considered as they may lead to more innovative and creative approaches toward natural areas management and biodiversity conservation. While we are intrigued by many components of the South African model and would like to see such ideas considered and evaluated in the United States, we recognize that it would take a transformational change in how America views and manages natural areas. Nonetheless, effective twenty-first century conservation and leadership requires consideration of creative and successful models from other countries.

\section{Conflict of Interests}

The authors declare that there is no conflict of interests regarding the publication of this paper.

\section{Acknowledgments}

This project was made possible in part by a grant from the National Park Foundation, the national charitable partner of America's national parks, and the National Park Service Capital Training Center. The authors thank Dave Druce at Hluhuwe-Imfolozi Provincial Park, Tristan Dickerson at Phinda Private Game Reserve, Sam Ferreira at Kruger National Park, and Jonathan Swart and Andre Burger at Welgevonden Private Game Reserve for their time and information. The authors thank the people within the National Park Service who supported the project.

\section{References}

[1] A. Phillips, "Turning ideas on their head: the new paradigm for protected areas," The George Wright Forum, vol. 20, no. 2, pp. 8-32, 2003.

[2] R. W. Sellers, Preserving Nature in the National Parks: A History, Yale University Press, 1997.

[3] D. S. Licht, R. Slotow, and J. Millspaugh, "A comparison of wildlife management in mid-size parks in South Africa and the 
United States," in Proceedings of the 2007 George Wright Society Conference: Protected Areas in a Changing World, pp. 300-307, George Wright Society, St. Paul, Minn, USA, 2008.

[4] P. J. Funston, "Conservation and management of lions in southern Africa: status, threats, utilization and the restoration option," in Management and Conservation of Large Carnivores in West and Central Africa, B. Croes, R. Buij, H.H. de Iongh, and H. Bauer, Eds., pp. 109-131, Institute of Environmental Sciences, Leiden, The Netherlands, 2008.

[5] P. A. Lindsey, J. T. du Toit, and M. G. L. Mills, "Area and prey requirements of African wild dogs under varying habitat conditions: implications for reintroductions," South African Journal of Wildlife Research, vol. 34, no. 1, pp. 77-86, 2004.

[6] P. A. Lindsey and H. T. Davies-Mostert, "South African action plan for the conservation of Cheetahs and African wild dogs," in Proceedings of the National Conservation Action Planning Workshop, Bela Bela, South Africa, 2009.

[7] R. Kettles and R. Slotow, "Management of free-ranging lions on an enclosed game reserve," South African Journal of Wildlife Research, vol. 39, no. 1, pp. 23-33, 2009.

[8] M. W. Hayward, J. O'Brien, and G. I. H. Kerley, "Carrying capacity of large African predators: predictions and tests," Biological Conservation, vol. 139, no. 1-2, pp. 219-229, 2007.

[9] National Park Service, Management Policies: The Guide to Managing the National Park System, D.o.t.I. National Park Service, Washington, DC, USA, 2006.

[10] D. S. Licht, J. J. Millspaugh, K. E. Kunkel, C. O. Kochanny, and R. O. Peterson, "Using small populations of wolves for ecosystem restoration and stewardship," BioScience, vol. 60, no. 2, pp. 147153, 2010.

[11] J. A. Vucetich, M. P. Nelson, and R. O. Peterson, "Should Isle Royale wolves be reintroduced? A case study on wilderness management in a changing world," The George Wright Forum, vol. 29, no. 1, pp. 126-147, 2012.

[12] R. Slotow, "Fencing for a purpose: a case study of elephants in South Africa," in Fencing for Conservation: Restriction of Evolutinary Potential or a Riposte to Threatening Processes, M. J. Somers and M. Hayward, Eds., pp. 91-104, Springer, New York, NY, USA, 2012.

[13] M. W. Hayward and G. I. H. Kerley, "Fencing for conservation: restriction of evolutionary potential or a riposte to threatening processes?" Biological Conservation, vol. 142, no. 1, pp. 1-13, 2009.

[14] C. Packer, A. Loveridge, S. Canney et al., "Conserving large carnivores: dollars and fence," Ecology Letters, vol. 16, no. 5, pp. 635-641, 2013.

[15] ABSA Group Economic Research, Game Ranch Profitability in South Africa, The SA Financial Sector Forum, ABSA, Rivonia, South Africa, 2003.

[16] Madikwe Development Task Team, The Madikwe Game Reserve Management Plan, N.W.P. Board, Rustenburg, South Africa, 1997.

[17] C. Ndabeni, M. Shroyer, W. Boonzaaier et al., The Heritage Park Model: A Partnership Approach to Park Expansion in Poor Rural Areas, U.F. Service, 2007.

[18] Peace Parks Foundation, “The Global Solution,” 2013, http:// www.peaceparks.org.

[19] R. Davies, Madikwe Game Reserve: A Decade of Progress, North West Parks Board, Rustenburg, South Africa, 2003.

[20] ICS, Madikwe Game Reserve Management Plan, N.W.P.T. Board, Rustenburg, South Africa, 2006.
[21] S. Mosidi, "Benefits beyond parks borders: the case of Madikwe Game Park, South Africa," in Communicating Protected Areas, D. Hamu, E. Auchincloss, and W. Goldstein, Eds., pp. 109-114, Commission on Education and Communication, IUCN, Gland, Switzerland, 2003.

[22] Y. Cui, E. Mahoney, and T. Herbowicz, "Economic benefits to local communities from national park visitation," in Natural Resource Report 2013, National Park Service, Fort Collins, Colo, USA, 2011.

[23] P. A. Lindsey, R. Alexander, M. G. L. Mills, S. Romañach, and R. Woodroffe, "Wildlife viewing preferences of visitors to protected areas in South Africa: implications for the role of ecotourism in conservation," Journal of Ecotourism, vol. 6, no. 1, pp. 19-33, 2007.

[24] P. A. Lindsey, R. Alexander, J. T. du Toit, and M. G. L. Mills, "The cost efficiency of wild dog conservation in South Africa," Conservation Biology, vol. 19, no. 4, pp. 1205-1214, 2005.

[25] D. S. Licht, Ecology and Economics of the Great Plains, University of Nebraska Press, Lincoln, Neb, USA, 1997.

[26] C. C. Gates, C. H. Freese, P. J.P. Gogan, and M. Kotzman, American Bison: Status Survey and Conservation Guidelines 2010, International Union for the Conservation of Nature, Gland, Switzerland, 2010.

[27] G. W. Vequist and D. S. Licht, Wildlife Watching in America's National Parks: A Seasonal Guide, Texas A\&M University Press, College Station, Tex, USA, 2013. 

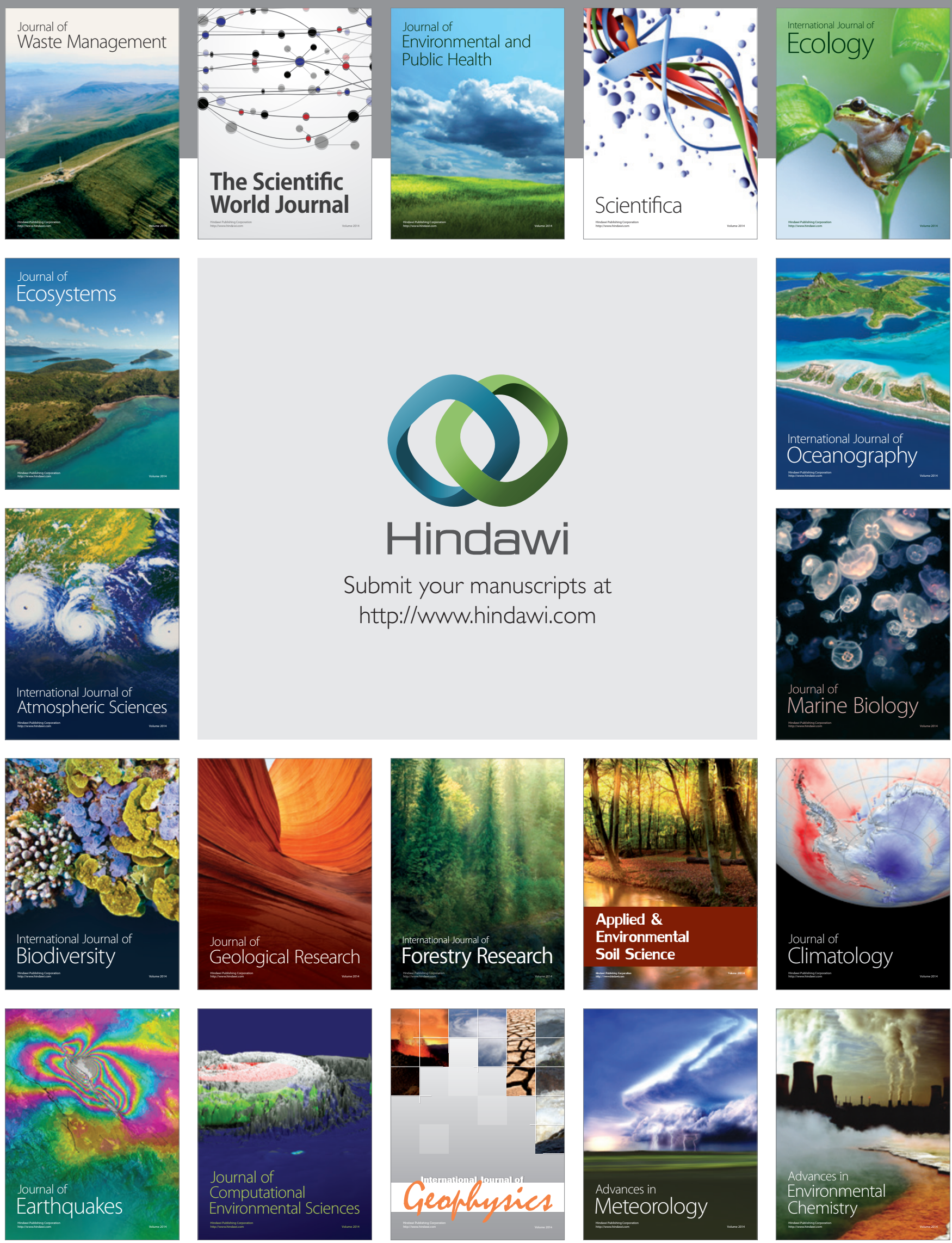